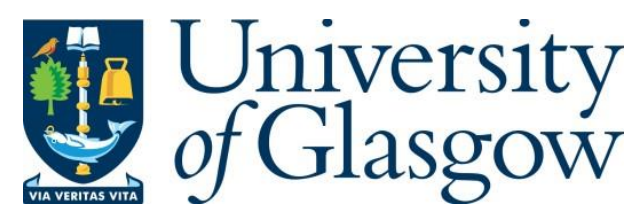

Schulting, R. J., Mcclatchie, M., Sheridan, A., Mclaughlin, R., Barratt, P. and Whitehouse, N. J. (2017) Radiocarbon dating of a multi-phase passage tomb on Baltinglass Hill, Co. Wicklow, Ireland. Proceedings of the Prehistoric Society, 83, pp. 305-323.

There may be differences between this version and the published version. You are advised to consult the publisher's version if you wish to cite from it.

http://eprints.gla.ac.uk/208757/

Deposited on: 6 February 2020

Enlighten - Research publications by members of the University of Glasgow http://eprints.gla.ac.uk 


\title{
Radiocarbon dating of a multi-phase passage tomb on Baltinglass Hill, Co. Wicklow
}

\author{
Rick J. Schulting \\ Meriel McClatchie \\ Alison Sheridan \\ Rowan McLaughlin \\ Phil Barratt \\ Nicki Whitehouse
}

\section{Abstract}

Baltinglass is a multi-chamber Neolithic passage tomb in Co. Wicklow, excavated in the 1930s. Here, we present the results of a radiocarbon dating programme on charred wheat grains and hazelnut shell found underlying the cairn, and on cremated human bone found within and near two of the monument's five chambers. The results are surprising, in that three of the six determinations on calcined bone pre-date by one or two centuries the charred cereals and hazelnut shells sealed under the cairn, dating to $c$. 3600-3400 cal BC. Of the remaining three bone results, one is coeval with the charred plant remains, while the final two can be placed in the period 3300/3200-2900 cal BC, that is more traditionally associated with developed passage tombs. We present a suggested sequence of construction beginning with a simple tomb lacking a cairn, followed by a burning event - perhaps a ritual preparation of the ground - involving the deposition of cereal grains and other materials, very rapidly and intentionally sealed under a layer of clay, in turn followed by at least two phases involving the construction of more substantial chambers and associated cairns. What was already a complex funerary monument has proven to be even more complex, with a history spanning at least six centuries.

\section{Introduction}

Developments in scientific archaeology, including the ability to radiocarbon date calcined bone and the Bayesian modelling of radiocarbon dates, have contributed to a resurgence of interest in refining the chronology of Irish passage tombs (Bayliss and O'Sullivan 2013; Bergh and Hensey 2013; Hensey et al. 2014; Kador et al. 2015; Schulting et al. forthcoming; Schulting 2014a). Aside from the important tomb of the Mound of the Hostages, Tara, Co. Meath (O'Sullivan 2005), the main focus has been on large passage tomb complexes, leaving a question over the place of more isolated sites. Baltinglass is a multi-phase, multi-chamber Neolithic passage tomb in County Wicklow, lying on the summit of a hill to the southeast of the Wicklow Mountains. The site is unusual for a passage tomb in yielding a deposit of 
charred cereal grain, along with charred hazelnut shells, a stone axehead, some flint scrapers and a flint javelin head, all within a layer of burnt material underlying the cairn. Cremated human remains were found in and near two of the chambers, and other finds include burnt fragments of two bone pins, a few sherds of pottery, a flint scraper, a smooth ovoid pebble and the partial remains of a single unburnt skeleton. The presence of these various materials and the site's multi-phase nature provided the opportunity for a radiocarbon dating programme, initially aimed simply at an understanding of the relationship between the deposit of charred cereals and the cremated remains. The results, however, have significance far beyond this, both for the monument's history, and for the wider typochronology of Irish passage tombs.

\section{The site}

The Baltinglass passage tomb is located on the summit of the hill of the same name, at an altitude of c. $382 \mathrm{~m}$ above sea level, on the junction of the townlands of Pinnacle, Coolinarrig Upper and Tuckmill Hill, Co. Wicklow (Figures 1,2). This commanding position is typical of passage tombs, in contrast to the lower elevations characteristic of court and portal tombs (Bergh 1995, 130, 161; Bergh 2002; 140; Cooney 2000, 142; Herity 1974, 41, 71; M. O’Kelly $1989,97)$. This is clearly seen in median elevations for Irish passage tombs $(145 \mathrm{~m}, \mathrm{n}=147)$ in comparison to court tombs $(89 \mathrm{~m}, \mathrm{n}=398)$ and portal tombs $(81 \mathrm{~m}, \mathrm{n}=185)($ McLaughlin et al. 2016, table 1).

Figure 1. Map showing location of the Baltinglass passage tomb and other sites mentioned in the text.

Figure 2. Baltinglass its landscape setting, with Chamber I to the left and Chamber III in immediate middle foreground. View to west. Photo: Professor William O’Brien.

Patrick T. Walshe excavated the site over three seasons from 1934 to 1936 (Walshe 1941). At the time of its excavation, it measured some $25.6 \mathrm{~m} \mathrm{~N}-\mathrm{S}$ by $27.7 \mathrm{~m} \mathrm{E}-\mathrm{W}$ in diameter. There is some discrepancy in the cairn's reported surviving height, which is given as $15 \mathrm{ft}$ (c. $4.6 \mathrm{~m})$ in the text (Walshe 1941, 222), while the section drawing (ibid., plate XVIII, fig. 2) indicates a height of only $c .10 \mathrm{ft}(3.0 \mathrm{~m})$. The latter measurement seems more reasonable, although the cairn would originally have been higher, since by 1907 it had already been partly denuded for the construction of a drystone wall. Large kerbstones were visible on three sides of the cairn 
even before excavation commenced, as were some of the stones of the large north chamber, Chamber I (Figure 3) (Walshe 1941). The excavations revealed a multi-phase monument with five chambers of various shapes, sizes and methods of construction (Figures 4, 5). What the excavator proposed as the earliest chamber to be constructed, Chamber II, appears to have been roughly of cruciform shape, with traces of a short passage, around $3 \mathrm{~m}$ long, leading to the SW edge of the first-phase cairn. The proposed subsequent enlargements of the cairn did not impact upon the southern quarter of the earlier cairn, so that Chamber II could have remained accessible.

Figure 3. Baltinglass, Chamber I. Part of Chamber II is visible to the upper right. View to $\sim$ south. Photo: Professor William O’Brien.

The placement of Chamber III in the sequence is less clear, not helped by the modern boundary wall running through this part of the cairn. Walshe described Chamber III as 'a long low rudely built structure' (Walshe 1941, 225); no trace of any covering mound or cairn seems to have been found. A long passage, defined by exceptionally small upright slabs just 2 " $(c .5 \mathrm{~cm})$ to $5 "(c .13 \mathrm{~cm})$ in height, ran between the outer and inner kerbs, leading to a roughly circular - though possibly originally cruciform - chamber (presumably constructed of similarly low stones) abutting the NW edge of the first cairn. The passage was divided into four small compartments by three small slabs laid cross-wise (ibid.); this is seen most clearly in an early draft of the site plan in the National Museum of Ireland (NMI) archives, which also specifies where cremated bone was found (Figure 5a). A subsequent draft plan refers to the passage as a 'series of chambers' (Figure 5b), which is how this area is presented on the final plan (Figure 4). In all three plans it appears that the kerb of the inner cairn overlies the stones of the chamber, although this is not explicitly stated in the published account. As shall be seen, the position of Chamber III in the monument's construction sequence is of central importance in this paper, and will be revisited in the discussion.

Chamber I is the largest, most imposing and best-preserved chamber in the monument, though it lacks any finds that would aid with its dating. The circular chamber had been built into the body of the earlier cairn, breaking the line of its kerb, with a partly surviving roofed passage running directly north for some 5 metres. Against the upright of the back wall was a large recumbent stone (c. $1.8 \mathrm{~m}$ long by $0.9 \mathrm{~m}$ wide and $0.6 \mathrm{~m}$ high) with what the excavator interpreted as an artificial depression some $15 \mathrm{~cm}$ deep on its upper surface (Walshe 1941, 224), recalling the well-known basin stones of the Brú na Bóinne passage tombs. This affinity 
is emphasised even further by the presence of an incised motif on the side of the stone facing into the chamber and down the passage (Figure 4). Chamber I and its associated cairn extension is clearly late in the Neolithic sequence, post-dating Chambers II and III.

Minimal information is available concerning the final two chambers, IV and V. Chamber IV takes the form of a small 'beehive' chamber, and is seen by the excavator as predating Chamber I; the fact that it lies within the first-phase cairn material, with its entrance opening out between two kerbstones, strongly suggests that it must have been constructed when that cairn was built (Walshe 1941, 235, plate XVII). Chamber V is described as a small ruined chamber or cist, enclosing an area around 6' by 3' (1.83m by $0.91 \mathrm{~m})$ Walshe 1941 , 226). It held no finds other than some charcoal and a lump of clay that may represent disintegrated pottery. On the plan its stones appear large enough to suggest a rectangular megalithic chamber, but too little information is available regarding its structure to say much more. Walshe considered it to be probably a late addition, post-dating even Chamber I (1941, 235), although he did not explain his reasoning. If it had indeed been an Early Bronze Age cist, as seems quite possible, then it might have been associated with a final episode of cairn enlargement during the Early Bronze Age, building out from the Chamber I cairn extension. There is, after all, ample evidence for Early Bronze Age re-use of passage tombs elsewhere, most notably at the Mound of the Hostages, Tara (O'Sullivan et al. 2013), as well as of earlier Neolithic court and portal tombs (Schulting 2014b; Schulting et al. 2012), though these examples do not involve modification of the structure.

\section{The finds}

Underlying the stones of the central part of the cairn was a layer of 'loam, rubble, and clay' $0.23 \mathrm{~m}$ thick, under which was found an intermittent thin black layer, another layer of firmer clay $0.15 \mathrm{~m}$ thick, and then another irregular black layer $1-2 \mathrm{~cm}$ thick. Between this and the bedrock was a layer of burnt yellow clay (Walshe 1941, 227) (Figure 4). The lowermost black layer contained abundant charcoal and two concentrations of charred hazelnut shells. Near one of these concentrations was found a polished stone axehead (Figure 6). Outside of the 'fire site' was found a bifacially-flaked flint javelin head with a broken tip, with a surviving length of c. $8 \mathrm{~cm}$ (ibid.) (Figure 7). In addition to those found in Chamber III, five flint scrapers - one of which had been burned - were recovered from the black layer underlying the cairn (ibid., 229, fig. 7). In a separate concentration of burnt material from the hazelnuts, between Chambers I and III and the cairn's centre, was a quantity of charred wheat grains (Triticum sp.), most probably emmer, though identification in the absence of chaff is 
difficult. Upon recent examination for sampling, both the hazelnut shells and the cereal grains were found to be extremely well preserved, suggesting burial soon after charring (note that O'Connor (in Walshe 1941, 236) is mistaken in his statement that the hazelnut shells and cereal grains were preserved by some inherent 'chemical disintegration' rather than by charring). Since flotation was not practised in the 1930s, the charred grains must have been hand-collected, implying a dense concentration, and probably a much larger total than the extant c. 200 grains in the NMI.

Aside from cremated human remains, finds in and around the chambers at Baltinglass were limited. Other than a flint scraper, Chamber I was empty. This could suggest that material was removed at some point before the recorded excavation - a not unlikely scenario given the easy access to the passage and chamber - although the apparent absence of even small fragments of calcined bone would be surprising if this were the case, assuming that they would have been noted and collected, which might be questioned given the early date and nature of the excavation. Alternatively, as suggested by ApSimon (1986, 9), the chamber may have held inhumed human remains that have not survived. (The presence of unburnt human remains in good condition in the upper levels of Chamber III does not challenge this interpretation, given its recent date, as detailed below). But this is also problematic, as cremation is very much part of the passage tomb tradition, even if it was not the exclusive funerary rite; rather, the deposition of both cremated and unburnt human remains appears to have occurred together, as alternative but contemporary rites (Cooney 2014; Schulting et al. forthcoming).

In Chamber II, cremated human remains belonging to at least one adult (probably more, to judge from the quantity of bone present: the material would benefit from a more thorough osteological study than was possible here) and one child were mixed with white quartz fragments. Only two sherds of pottery were found, one in the chamber, and another, a rim sherd, amongst the spread of cremated bone found just outside the chamber (Walshe 1941, 224-5, fig. 2) (Figure 8). Whether this bone belongs to the same individuals as those from inside the chamber is unclear, and needs further research. The sherds are both decorated coarseware sherds belonging to the tradition generally referred to as 'Carrowkeel ware', and it is not impossible that they belong to the same pot, although a re-examination of the sherds would be necessary to verify that. Although once thought of as 'passage tomb pottery', this is an oversimplification, as finds from non-passage tomb contexts make clear (Sheridan 1995).

Chamber III also held the cremated remains of at least one adult and one child (again, more individuals than this were probably present), mixed with charcoal and white quartz. The 
chamber's inner recess is noted as holding a large quantity of cremated bone, some of which was in a small 'hollow or basin-shaped stone which was found on a large slab which was lying immediately outside the chamber on the south-east side' (Walshe 1941, 225, plate XVI, fig. 2). Additional cremated bone was present in the 'chambers' of the passage (Figure 5a). Three flint scrapers were also recovered from the chamber, along with two burnt fragments of worked bone and a small, thick, heavily-worn (but seemingly undecorated) pottery sherd (ibid., fig. 2.3). The worked bone fragments appear to be the heads of slender pins with one having a constriction, and the other, a perforation close to its end (Walshe 1941, 230, fig. 4A, B) (Figure 9). These features would have allowed the fixing of a thread or thong that would have passed around the other end of the pin to prevent it from slipping loose when in use. Pins, possibly used to fasten funerary garments among other uses, are not an uncommon find in Irish passage tombs (e.g. Hensey and Bergh 2013), and a parallel for the slender perforated pin can be cited from Fourknocks I, Co. Meath (Herity 1974, fig. 144.34). Although not mentioned either in the publication or in the site archive, the upper levels of Chamber III held a group of well-preserved, unburnt longbones probably belonging to a single adult. This individual will be revisited below.

Along with the small quartz fragments mixed with the calcined bone, quartz cobbles were noted around the cairn's circumference, leading Walshe to suggest that the cairn may have had a capping of quartz at some stage, and that this might have had some significance for the builders $(1941,229)$, an interpretation very much in keeping with more recent views (cf. Fowler and Cummings 2003). Such an association with quartz is a well-known feature of Irish passage tombs (Bergh 1995, 153; Eogan 1974; O’Kelly 1982; O’Sullivan 1993a), its prominent use at Knowth and Newgrange being well documented (e.g. Eogan 1984, 106; Meighan et al. 2003; Mitchell 1992; Stout and Stout 2008, 1-4, 6-7, 58-60). In Ireland and indeed in western Britain there is an element of the longue durée to the mineral's connection with the dead, from at least the Early Neolithic to medieval and more recent times (Cooney 2000, 177; Fowler and Cummings 2003; Hemp 1930; Mitchell 1884; Thompson 2005).

In addition to the practice of cremation and the presence of Carrowkeel ware pottery, bone pins and quartz spreads, the place of Baltinglass in the passage tomb tradition is further supported by the occurrence of 'passage tomb art' in Chambers I and II and on two kerbstones of the inner kerb. Spiral designs are found on one of the kerbstones, and on two uprights in Chamber II (Figure 4; Walshe 1941, fig. 8G, K, L). Walshe (1941, 233) immediately made the obvious comparison with megalithic art at Newgrange and Loughcrew (of course Knowth 
must also be mentioned in this regard (Eogan 1986; C. O'Kelly 1973; O'Sullivan 1993b), as well as the passage tomb at Seefin in the north of Co. Wicklow, though the rectilinear chevrons and lozenges carved on two stones of the passage there (Macalister 1933) are very different from anything at Baltinglass, with what are perhaps the closest parallels being found at Barclodiad y Gawres on Anglesey, North Wales (Rynne 1963), although comparable motifs also occur in the Brú na Bóinne (Herity 1974, 73; C. O’Kelly 1983). Designs more akin to those at Baltinglass can be found on the stones of the destroyed passage tomb at Tornant Upper, Co. Wicklow, now in the National Museum of Ireland (Stout 1989). There is also what Walshe $(1941,234)$ refers to as a 'curious design', a rounded rectangle motif on the outward facing side of the basin stone in Chamber I, narrowing at the bottom and bearing a central vertical line, and two upper horizontal cross-bars (ibid., fig. 8J; Figure 4, J).

Figure 4. Plan and section of the Baltinglass passage tomb (after Walshe 1941, plate XVIII, with overlain rock art rubbings from figs. 8 and 9, not to scale). Location of the saddle quern from Cooney (1981, fig. 28a). The exact location of the dated cremated remains from Chamber II is uncertain.

Figure 5. Unpublished plans of the Baltinglass passage tomb: a) sketch plan by Padraic T Breathnach specifying the locations of the cremated remains, dated 5/9/1934; b) plan dated 1935, with annotations as marked on original; note the different location of the southernmost motif on this and the published plan ('G' on Figure 4) (National Museum of Ireland archive)

\section{$A M S{ }^{14} C$ dating}

Seven human bone samples and two cereal grains were selected for AMS ${ }^{14} \mathrm{C}$ dating, undertaken at the ${ }^{14} \mathrm{CHRONO}$ laboratory at Queen's University Belfast. All but one of the human bone samples was fully calcined (hence no stable nitrogen isotope values are available, and stable carbon isotope values are unrelated to diet). The degree of warping and the curved 'fingernail' fracture lines are consistent with the burning of fleshed corpses, as opposed to dry bone (McKinley and Bond 2001). Cremated bone was recovered from three contexts, each of which is represented here by two samples: the interior of Chamber II (from an unspecified chamber segment), a deposit outside Chamber II, and the central part of Chamber III. There is no guarantee that distinct individuals are represented, with the exception of sample E11:62-2, 
which is of subadult size, whereas the others are of adult size. Unfortunately, as noted above, no material suitable for dating was recovered from Chamber I. The only unburnt sample is a human radius, part of a group of largely complete longbones reportedly (see below) found in the upper levels of Chamber III, and almost certainly belonging to a single adult individual. The two charred wheat grains and the charred hazelnut shell derive from two different locations within the black, charcoal-rich layer found underlying the cairn (Walshe 1941, 228).

The results all fall within the Neolithic period, with the exception of the unburnt human radius from the upper levels of Chamber III, which proved to be very recent (cal AD 15141660; UBA-14753: $289 \pm 24 \mathrm{BP} ; \delta^{13} \mathrm{C}=-20.1 \%$ ) (all ranges are quoted at $95.4 \%$ confidence unless otherwise noted). There is no indication of any contamination, so that the result does reflect the true age of this individual. Interestingly, no mention was made in either the published report (Walshe 1941) or the surviving site archive (comprising a series of notes, sketch plans, and correspondence relating to the excavations) of the recovery of any unburnt bone. The attribution to Baltinglass, and specifically to the upper levels of Chamber III, derives from its associated paper label in the National Museum of Ireland. This discrepancy was noted by Etienne Rynne in a comment added to the site files (NMI archives, 5/11/1960). Also not mentioned in the published paper is a 'decorated lead stud' (E11:183; Figure 10) listed in the NMI site files, though no specific findspot is provided; the stud or rather button is entirely consistent with the sixteenth-seventeenth century date on the human bone (A. Halpin, pers. comm.; E. Standley, pers. comm.). One possible explanation is that, given the very good condition of the bones and their position in the site's upper levels, the excavator chose not to mention them in his report, considering them recent and perhaps with the potential of being politically sensitive (i.e., related to the Irish Civil War of 1922-23). If so, the decision to keep and label the remains at all is puzzling. AD 1514-1660 falls within an interesting if turbulent time, during the conquest of Ireland by Henry VIII. In any case, while intriguing, this find is not discussed further here.

The calcined human bone determinations span an unexpectedly large range, from 3946$3715 \mathrm{cal}$ BC to 3011-2887 cal BC (Table 1). Taken at face value, the results suggest the presence of as many as five phases of activity involving the deposition of cremated remains (Figure 11). The earliest result, 3946-3715 cal BC (UBA-14759), was obtained from a calcined bone sample from Chamber III. Next is a calcined bone sample found outside Chamber II at 3706-3637 cal BC (UBA-14755), indistinguishable from the second result from Chamber III at 3710-3637 cal BC (UBA-14758). The second sample from outside 
Chamber II falls in the range 3635-3376 cal BC (UBA-14754), contemporary with the results for the two wheat grains and the hazelnut shell (UBA-14812, 14813, 23040), which can be successfully combined using in OxCal 4.2 (4717 $\pm 17 \mathrm{BP}, 3630-3378 \mathrm{cal} \mathrm{BC}, \chi^{2} \mathrm{~T}=0.6(5 \%$, 6.0)). Finally, the two calcined bone samples from the interior of Chamber II reflect the most recent radiocarbon-dated Neolithic activity, at 3331-2931 cal BC (UBA-14757) and 30112887 cal BC (UBA-14756).

The location of the charred grain/hazelnut shell deposit underlying the cairn and the cremated human bone from within and outside of the chambers should provide the opportunity for Bayesian modelling making use of this stratigraphic relationship (cf. Bronk Ramsey 2009; Buck et al. 1996). However, it is clear that the two cereal and the hazelnut determinations, while perfectly consistent with one another (and therefore with a short-lived episode of activity), post-date three of the calcined bone results. Not surprisingly, then, such a model is rejected outright, with individual agreement indices of $c .5 \%$ (versus the required minimum 60\% - see Bayliss et al. 2007 for an explanation of this statistic) for the three early calcined bone results, leading to the rejection of the model as a whole $\left(\mathrm{A}_{\text {model }}=5 \%\right)$. The implications of this for reconstructing the sequence of activities on Baltinglass Hill are explored below.

\begin{tabular}{|l|l|l|l|l|l|l|l|}
\hline Sample no. & Context & Material & UBA- & ${ }^{14}$ C BP & \pm & $95.4 \%$ cal BC \\
\hline E11:61-1 & outside Ch II & radius/ulna shaft frag & 14754 & 4726 & 41 & 3635 & 3376 \\
\hline E11:61-2 & outside Ch II & longbone shaft frag & 14755 & 4879 & 29 & 3706 & 3637 \\
\hline E11:62-1 & Chamber II & cranial frag, nuchal area & 14756 & 4310 & 25 & 3011 & 2887 \\
\hline E11:62-2 & Chamber II & distal humerus, subadult? & 14757 & 4441 & 32 & 3331 & 2931 \\
\hline E11:64-1 & Chamber III & longbone shaft frag & 14758 & 4885 & 30 & 3710 & 3637 \\
\hline E11:64-2 & Chamber III & cranial frag & 14759 & 5031 & 25 & 3946 & 3715 \\
\hline E11:58-1 & Chamber III & radius shaft, upper level & 14753 & 289 & 24 & AD 1514-1660 \\
\hline E11:181-1 & under cairn & charred wheat grain & 14811 & 4718 & 26 & 3632 & 3376 \\
\hline E11:181-2 & under cairn & charred wheat grain & 14812 & 4729 & 37 & 3635 & 3377 \\
\hline E11:182 & under cairn & charred hazelnut shell & 23040 & 4693 & 36 & 3630 & 3370 \\
\hline
\end{tabular}

Table 1. AMS ${ }^{14} \mathrm{C}$ results on human bone and charred plant remains from Baltinglass. Sample E11:58-1 is on unburnt bone; all other human samples are fully calcined.

\section{Discussion}

The radiocarbon results from Baltinglass are intriguing in a number of respects. Foremost is the unexpectedly early date of 3946-3715 cal BC for a calcined human bone from Chamber III. To put this into context, this determination is currently among the very earliest from a definite Neolithic context in all of Ireland. It predates the modelled earliest deposition thus far 
known for human remains in court tombs, placed at 3700-3550 BC (Schulting et al. 2012, Table 6; date ranges resulting from Bayesian models are presented in italics, in 'BC' rather tha 'cal BC' since the modelled range no longer relies entirely on the calibration curve), as well as the Irish Neolithic 'house horizon', the onset of which is very robustly modelled on short-lived materials - mainly charred cereal grains - as 3720-3660 BC (McSparron 2008; Schulting 2011; Whitehouse et al. 2014). A recent Bayesian model on 25 dated bone and antler pins from two simple passage tombs at Carrowmore, Co. Sligo confirms a phase of deposition at those passage tombs commencing 3775-3520 BC (Bergh and Hensey 2013), contemporary with both the use of court tombs and the construction of rectangular timber buildings. Excluding the controversial dates from the causewayed enclosure at Magheraboy, Co. Sligo, the earliest result from Baltinglass also largely pre-dates Cooney et al.'s (2011, 663) model 2 for the beginning of the Irish Neolithic at 3750-3680 BC. Their model 3 , however, accepts the possibility of an earlier beginning at 3850-3740 BC, a date range that is nearer Sheridan's (2010) proposed onset of the Neolithic (including a late fifth/early fourth millennium start for the passage tomb tradition in Ireland) as well as the robust new dating evidence from Poulnabrone (Lynch 2014; Schulting 2014b), discussed further below.

At present, the only other directly radiocarbon-dated Neolithic presence in Ireland prior to $3750 \mathrm{BC}$ - if one sets aside: 1) the early domestic cattle bones from the Mesolithic site at Ferriter's Cove, Co. Kerry (Woodman et al. 1999); 2) the abovementioned Magheraboy dates; and 3) the problematic dates obtained for some of the Carrowmore simple passage tombs by Göran Burenhult (Bergh and Hensey 2013) - comes from the portal tomb of Poulnabrone, Co. Clare, with the deposition of unburnt human remains modelled as commencing 3820-3745 $B C$ (Schulting 2014b, Table 5.3). A single result from a large series of AMS ${ }^{14} \mathrm{C}$ dates on calcined human bone from Knowth is comparable to Baltinglass, but its validity has been called into question in the Bayesian modelling of the site as being anomalously early (Schulting et al. forthcoming). This may be a statistical outlier, or else the sample may actually be a burnt animal bone from the Neolithic settlement underlying, and therefore predating, the construction of the main mound at Knowth (Eogan and Roche 1997). Similarly, though for different reasons, there is uncertainty concerning the interpretation of two early outlying dates on calcined bone from the court tomb at Altanagh, Co. Tyrone: 3942-3710 cal BC (UBA-14390: $5020 \pm 29$ BP) and 3912-3693 cal BC (UBA-14392: $4987 \pm 26$ BP) although such dates are not impossibly early for the traditional Carinated Bowl pottery that was also found in this monument (Murphy and Ó Donnabháin forthcoming). 
One possibility for the early date from Baltinglass is that cremated bone fragments were brought to the site and placed in Chamber III some centuries after the cremation of the body. A selection of calcined bone may either have been curated, or retrieved from an earlier site. A similar practice was initially suggested as an explanation for the early dates on human bone from the Poulnabrone portal tomb and the lack of any correlation with the deposit's stratigraphy (Lynch and Ó Donnabháin and 1994). However, the final publication of the site which includes new analyses of the human skeletal assemblage and a new series of AMS ${ }^{14} \mathrm{C}$ determinations on unburnt bone - makes it clear that this is very unlikely, and that the tomb saw successive primary inhumations with considerable subsequent disturbance (Schulting 2014b). While still possible for Baltinglass, it is difficult to find a comparable example of the practice of placing older human bone in a Neolithic monument that holds up to close scrutiny from either Ireland or Britain (cf. Schulting et al. 2010).

Another possible explanation that could apply to all the aforementioned early dates on calcined bone from Neolithic monumental mortuary contexts is that they have been affected by carbon from the fuel used in the cremation pyre. Experiments have shown that, during cremation, bone becomes susceptible to incorporating carbon from the $\mathrm{CO}_{2}$ emitted by the pyre fuel (Huls et al. 2010; Snoeck et al. 2014; Zazzo et al. 2009; 2012). In most circumstances, the wood used for cremation pyres was probably branch wood or small trunks with an age measured in decades, making it comparable to the age of the adult human corpse, given the slow turnover rate of ${ }^{14} \mathrm{C}$ in bone collagen (Hedges et al. 2007). Thus, early comparisons of cremated human bone and associated charcoal did not identify significant offsets between the two, implying that the dating of calcined bone gave reliable results for the actual age of the sample (Lanting and Brindley 1998; Lanting et al. 2001; Sheridan 2003). However, if older wood - such as structural oak timbers from an Early Neolithic house (cf. McLaughlin et al. 2016) - had been used for the cremation pyre fuel, then it is entirely possible (indeed, almost certain) that the resulting $\mathrm{AMS}{ }^{14} \mathrm{C}$ measurement on calcined bone would be one to two centuries too old (Snoeck et al. 2014). This issue will be very difficult to resolve, and comes down to an interpretation based ultimately on the accumulation of more radiocarbon dates from similar contexts, and a balance of probabilities regarding the likelihood of precocious outliers from such contexts. This issue does not arise with Poulnabrone, since the human remains there were unburnt, well preserved, and not subject to any discernible reservoir offsets from either marine or freshwater resources (i.e., the associated $\delta^{13} \mathrm{C}$ and $\delta^{15} \mathrm{~N}$ values indicate no appreciable consumption of such resources - 
Ditchfield 2014). As far as the Baltinglass date is concerned, the 'old carbon' effect cannot be ruled out as a possible explanation.

If, however, the early date is valid, and if we are not dealing with the importation of curated ancient cremated remains, then this raises the intriguing possibility that Chamber III an anomalous structure as far as the canon of Irish passage tomb architecture is concerned had genuinely been constructed and used early in the fourth millennium BC. That Chamber III belongs to the passage tomb tradition is suggested by its hilltop position, by the later presence of unquestionable passage tomb chambers in the monument, by the practice of cremation, associated with the use of bone pins probably used to fasten secure funerary garments or as hair ornaments (Herity 1974, 134), and by the deposition of some cremated remains within a stone basin-like receptacle. However, there are no parallels for the use of basin stones among the earliest dated passage tombs in Ireland; and despite a vague similarity in ground plan to some of the simple passage tombs in the Carrowmore cemetery, Chamber III contrasts with Ireland's simple passage tombs in the diminutive scale of its construction and in the absence of a large (or indeed any) capstone. The single abraded sherd found in Chamber III fails to provide any additional clues. The absence of decoration suggests that it is not Carrowkeel Ware, yet its thickness and coarse appearance shows that it unlikely to be an example of traditional Carinated Bowl pottery either. While occasional thick and relatively coarse-textured pots have been found in the traditional Carinated Bowl repertoire, other characteristics of Chamber III point away from an association with the 'Carinated Bowl Neolithic' (Sheridan 2010).

Aside from the intriguing early date of 3946-3715 cal BC, perhaps the most important result of the present dating programme is the evidence for the monument's use from c. $3700 / 3600$ to $3400 \mathrm{cal} \mathrm{BC}$, based on multiple $\mathrm{AMS}{ }^{14} \mathrm{C}$ dates on cremated human bone from Chamber III and outside Chamber II, and on charred wheat grains and hazelnut shell from underneath the cairn (Figure 10). Unlike the situation with a single outlier, it is unlikely though not inconceivable - that all three calcined bone determinations would be affected by old fuel. If the use of old timbers for funerary pyres had been a common practice, then many more examples of older dates might be expected to have been observed in the large series of dates on calcined bone from Knowth and the Mound of the Hostage, Tara, rather than just one potential example from Knowth. Moreover, the charred cereal and hazelnut shell results confirm activity here prior to c. $3370 \mathrm{cal} \mathrm{BC}$, a date that furthermore is consistent with what we understand to be the temporal currency of flint javelin heads in Ireland (Nelis 2004), a category of artefact which was discussed by Pat Collins in 1981 (Collins 1981; see also 
Woodman et al. 2006, 144-9) and which has been associated with court and portal tombs as well as with the Listoghil passage tomb at Carrowmore (Bergh 1995, 199; Herity 1974, 264 and fig. 149.15). On the currently available information, and as detailed below, this clearly pre-dates the use of the developed passage tombs of the Brú na Bóinne and of the Mound of the Hostages, Tara, Co Meath.

In an island-wide context, this phase of activity at Baltinglass is contemporary with the initial use of court tombs (Schulting et al. 2012), the continuing use of the earliest portal tombs (Schulting 2014b), the use of simple passage tombs of Carrowmore (Bergh and Hensey 2013), and the onset of the Irish Neolithic 'house horizon' (McSparron 2008; Schulting 2011; Whitehouse et al. 2014). But this large-scale pattern is replicated at the local level. The Linkardstown cist at Ballintruer More is located less than $5 \mathrm{~km}$ to the north of Baltinglass (Raftery 1973) (Figure 1). The radiocarbon determination of 3705-3372 cal BC (GrN-10469: $4800 \pm 70 \mathrm{BP}$ ) on a single disarticulated unburnt adult skeleton from here (Brindley et al. 1983 ) is fully contemporary with this second phase of burial activity at the passage tomb. While portal tombs and court tombs have long been accepted as at least partly contemporary (Schulting et al. 2012, fig. 10), that two such different monument types, located in very different topographic settings (Ballintruer More is at ca. 170m elevation, which, although very high for this monument class, is low-lying in the context of its surroundings, compared with the $382 \mathrm{~m}$ hilltop location of Baltinglass) should be in use at what is ostensibly the same time is perhaps more remarkable.

The presence of the charred wheat grains, hazelnut shells and artefacts (including an axehead and a flint javelin head) underlying the cairn associated with Chamber II requires an explanation. That the cereals, nuts and artefacts had not simply trickled down from the overlying cairn material is clear from their position in a sealed stratigraphic context: they were found in a layer of burnt (and unburnt) material underlying a layer of compact clay some $0.15 \mathrm{~m}$ thick, in turn capped by $0.23 \mathrm{~m}$ of clay and rubble, the whole sealed by cairn material. Was this material, as Walshe implied, related to a ritual associated with preparations for the construction of the cairn and its chamber? Does it relate to funerary pyres, for cremating the individuals whose remains ended up in Chamber II? Or could it derive from a pre-cairn settlement?

Of these three suggestions, the last seems the least probable. The hilltop position is a most unlikely location for a Neolithic domestic structure (Smyth 2014) and the site is clearly not a hilltop causewayed enclosure, as at Donegore Hill, Co. Antrim (Mallory et al. 2011). The discovery of a saddle quern in 1980 amongst the cairn stones inside the southern kerb, 
near where the passage entrance to Chamber II would have been (Cooney 1981, fig. 29), does not give support to a 'Neolithic hilltop settlement' interpretation since, quite apart from its stratigraphic dissociation with the burnt layer, the quern could easily relate to much later activity associated with the bivallate hillfort of Rathcoran on Baltinglass Hill, as Cooney points out (ibid., 105). Finally, the dating evidence does not fit with this in any case, since the site had seen earlier use for mortuary purposes.

If the burning layer recognised during the excavations is in fact the remnant of a funeral pyre, or a series of pyres, then it is possible that wheat and hazelnuts were thrown onto the fire as part of the rites, as seems to have been the case with some Bronze Age cremations (Jones 2007). That such finds are not duplicated at other passage tombs could then relate to fact that pyre sites are rarely encountered (a notable exception being Fourknocks II - Hartnett 1971). However, the absence of any calcined bone from this burnt layer - despite the fact that the excavators had been sufficiently careful and observant as to recover small wheat grains and hazelnut shells - militates against the 'pyre hypothesis'.

Thus, the most plausible interpretation is that this material does indeed relate to the ritual preparation of the site prior to the construction of Chamber II and its associated cairn. Such a practice appears to have antecedents in the court tomb tradition (Collins 1954; O'Kelly 1958). The fact that one of the two dates on cremated bone found outside Chamber II (UBA14754 ) is contemporary with the cereal grain/hazelnut shell dates is consistent with this hypothesis, suggesting - as Walshe had indeed argued - that there had not been a long interval between the episode of burning and the construction of the cairn (which, as we have seen, appears to be related to the construction of Chamber II). It remains to be seen whether the wheat could have been grown locally: Cooney had suggested that during the Neolithic, arable farming could theoretically have been possible near the hill's summit (ibid., 105). In any case, cultivation would certainly have been possible in the area immediately below the hill.

The nearest palaeoenvironmental sequence to the site is $c .10 \mathrm{~km}$ away, at Arts Lough, Co. Wicklow, a small upland lake situated at an altitude of 490 metres. During the main period of usage of Baltinglass, Pinus, Ulmus, Quercus, Corylus and Betula dominate the landscape, with increasing levels of Alnus (Bradshaw and McGee 1988). Ulmus habitats decline just before 3000 cal BC, coinciding with a relatively brief expansion of Fraxinus, a tree that often occupies secondary gaps in the forest. In-wash of organic material into the lake and low levels of Plantago pollen (an agricultural indicator of disturbance) are also evident at this time, suggesting disturbance and clearance within the lake catchment from c. $3000 \mathrm{cal}$ BC. 
Plantago does not become persistent until after c. 2000 cal BC, however, whilst cereal-type pollen appears only from $c .1500 \mathrm{cal} \mathrm{BC}$. This record suggests that upland areas around Arts Lough, and by extension around Baltinglass, likely remained relatively undisturbed during the $4^{\text {th }}$ millennium. It was only during the Late Neolithic and Bronze Age that we see much evidence for sustained agricultural activities. Of course, sheltered areas away from hillsides and uplands likely supported agricultural activities as has been previously demonstrated (McClatchie et al. 2014; 2016).

As for the other dates on cremated bone relating to Chamber II, the fact that UBA14755 (3706-3637 cal BC) on bone from just outside the chamber is contemporary with UBA-14758 (3710-3637 cal BC) on bone from Chamber III could be interpreted to mean that the contents of Chamber III were disturbed when Chamber II was built. It could be that some of the by-then ancestral human remains were transferred from Chamber III to Chamber II, only to be cast out of that chamber during a subsequent episode of disturbance.

The other two dates from cremated bone associated with Chamber II are from inside the chamber, and they fall towards the end of the monument's Neolithic use-life, at least in terms of the dates presented here (it is highly likely that the Carrowkeel ware sherds found inside and outside Chamber II belong to this phase of activity.) Yet these two results, lying in the range 3300-2900 cal BC, are the only ones that are consistent with the increasingly wellsupported chronology of the developed passage tombs of the Brú na Bóinne, the Mound of the Hostages, Tara, Co. Meath and Carrowkeel, Co. Sligo. The preferred Bayesian model for a large series of dates on both cremated and unburnt human remains from the passage tomb complex at Knowth places the start of burial activity there between 3160 and 3045 BC (Schulting et al. forthcoming, Table 4.10). The start of burial deposition at the Mound of the Hostages, Tara, is similarly modelled at 3285-3075 BC (Bayliss and O'Sullivan 2013). While no human bone dates are yet available for Newgrange, a Bayesian model of the available dates relating to various phases of construction suggest that the turf mound was initiated sometime in the range 3305-3125 BC, and the overlying cairn in the range 3190-2865 BC (Schulting 2014a). The wider ranges for Newgrange are the result of the much smaller number of dates, combined with the uncertainties introduced by the well-known late fourth millennium plateau in the calibration curve (Ashmore 2004; Schulting et al. forthcoming). New results on cremated human bone from Carrowkeel fall in this same period (Hensey et al. 2014; Kador et al. 2015). It is noteworthy that Chamber II held the 'Carrowkeel' sherds and the spiral motifs on its uprights; again, both are classic passage tomb associations. 
At first glance these results are not in agreement with the excavator's suggestion that Chamber II belonged to the earliest phase of the monument. However, it must be recalled that the expansion of the cairn with the construction of Chamber I did not block access to the passage to Chamber II, so that cremated bone could continue to be deposited there after Chamber I was built.

While the larger and more imposing Chamber I is undated, several features suggest that it was probably constructed and used between 3300/3200 BC and 2900 BC. Stratigraphically, it clearly post-dates the construction of Chamber II, and both its scale and the presence of a sizeable basin stone suggest an aggrandisement of the monument consistent with the emulation of developments in the Boyne Valley. The presence of 'passage tomb art', not only on the basin stone but also on kerb stone F of the enlarged cairn - in the form of a crude spiral - offer further pointers in the same direction. As noted above, Chamber II was still being used for the deposition of cremated human remains between 3300/3200 cal BC and $2900 \mathrm{cal}$ BC, and so some overlap in the use of Chambers I and II seems likely.

As noted above, there are no dates relating to Chambers IV and V but it seems likely, on structural grounds, that Chamber IV had been built when the first-phase cairn was constructed, and it is not unreasonable to argue that Chamber V may be an Early Bronze Age cist, associated with a final phase of cairn aggrandisement.

Figure 11. Plot of calibrated AMS results from Baltinglass (OxCal 4.2.4). All dates from the chambers are on calcined human bone.

Putting together all the evidence outlined above, and acknowledging the problematic nature of some of it, we can now attempt a provisional account of the sequence of activities on Baltinglass Hill as follows:

Phase 1. Construction of the simple, small monument Chamber III and deposition of cremated remains within it, pre-dating $3600 \mathrm{cal}$ BC (EN II in Whitehouse et al. 2014, Tab. 1), possibly as early as c. 3900 cal BC (EN I), though anything pre-3700 BC relies entirely on the acceptance of the earliest result, UBA-14759. Given the absence of substantial uprights, Chamber III may have lacked a cairn altogether, or had a modest covering mound that has not survived: some protection seems to be implied by the presence of the cremated remains. A question can be raised concerning the interpretation of the two statistically identical results within the range c. 3700-3640 cal BC on calcined bone found within Chamber III and outside 
Chamber II. Does the latter, more substantial chamber also belong to this early phase, or was this bone fragment somehow originally associated with Chamber III, or, finally, is this determination affected by the incorporation of old carbon from the pyre fuel?

Phase 2. Substantial on-site burning - perhaps as part of a purification rite - leading to the deposition of artefacts (including the axehead and javelin head, bone pins, etc.), hazelnuts and cereals, with the latter dating to $c .3600-3400 \mathrm{cal}$ BC (MN I). This was then sealed by a substantial layer of compacted clay and rubble (the implication being that this does not extend underneath Chamber III). The excellent preservation condition of the charred cereals and hazelnut shells, many of which were in very large fragments, suggests that this covering quickly followed their initial deposition. That it may not have been a unitary event, however, is seen by the second, if irregular, black layer found within the clay/rubble (see section on Figure 4).

Phase 3. Construction of Chamber II (and the 'beehive' Chamber IV?), and of first kerbed cairn covering these chambers and overlying part of Chamber III. The date of 3635-3376 cal $\mathrm{BC}(\mathrm{MN}$ I) from cremated bone that had probably subsequently been cast out from Chamber II suggests that this episode of construction followed on from the 'purification and preparation' activities of Phase 2 without a significant interval. As suggested above, the presence of an older bone fragment dating to 3706-3637 cal BC outside Chamber II could be due to the removal of some human remains from Chamber III when Chamber II was built, or to an 'old wood' effect.

Phase 4. If not already built in phase 3 , the construction of the inner cairn and continued deposition of cremated remains in Chamber II, dating to what appears to be an island-wide horizon of the construction and use of developed passage tombs in the period 3300/3200$2900 \mathrm{cal}$ BC (MN II/LN I). The circular motifs on an upright of Chamber II (K) and a nearby kerb stone $(\mathrm{G})$, along with the less well-defined motif $(\mathrm{H})$ on an inner kerb stone on the west side of the first cairn, would likely have been created at this time. The sherds of Carrowkeel ware found inside and outside the chamber probably belong to this phase. It may be during Chamber II's re-use that older cremated bone was cast out of the chamber.

Phase 5. The addition of the larger second cairn with its substantial Chamber I, and potentially also Chamber V (though see below). The dating of this is uncertain, but is almost certainly to be found within the range given for Phase 4 (MN II/LN I), and indeed may have followed on relatively quickly from the construction of the initial cairn, though we are dealing with a number of centuries here. The alignment of the outer kerb itself does not suggest a unitary construction, so that this may have been subject to a series of modifications. The passage 
tomb art on the outer kerb stone near Chamber V $(\mathrm{F})$ and the unusual motif on the basin stone of Chamber I (J) can be attributed to Phase 5, with the caveat that they could equally be recycled stones from Phase 4.

Phase 6? Potential Early Bronze Age re-use of the monument, with the addition of a cist (Chamber V) and possibly a final enlargement of the cairn.

It is difficult to make comparisons with the structure of the other passage tombs of Co. Wicklow, since very little information is available. The only other recorded excavation was undertaken at Seefin, at approximately the same time as that at Baltinglass. Only a brief report has been published, but the large cairn's central chamber takes the form of a classic passage tomb with a series of recesses set around a central space (Macalister 1932, fig. 2). It should thus be contemporary with phase 4 at Baltinglass. The example at Upper Tornant was destroyed before being properly recorded.

\section{Conclusions}

The radiocarbon dates reported on here have not only shed new light on the lengthy sequence of activities and construction at this complex monument, but have also provided the first directly-dated evidence relating to passage tomb construction and use in eastern Ireland outside the Brú na Bóinne and Tara. They demonstrate the value of targeted dating programmes, and the pressing need for more such programmes in order to clarify the overall development of the passage tomb tradition in Ireland (cf. Schulting et al. forthcoming; Sheridan 1986; Hensey 2015).

Among the questions that this exercise has thrown up is the nature, significance and date of the curious Chamber III structure. If the earliest date is valid, then this ranks among the earliest dated funerary monuments in Neolithic Ireland, contributing to the evidence for the appearance of the Irish Neolithic prior to the $38^{\text {th }}$ century BC. Even if the date is invalid, others on calcined bone from Chambers III and outside Chamber II suggest that it was in existence by the $38^{\text {th }} / 37^{\text {th }}$ century cal BC, and its possible relationship with other monuments belonging to the early stages of the passage tomb tradition in Ireland needs to be explored in more depth.

The other radiocarbon dates for Baltinglass make it clear that early activity at this monument was coeval with the use of court tombs, portal tombs and Linkardstown cists, as well as deposition in the simple passage tombs of Carrowmore in the west of Ireland, predating by some centuries the earliest use of the developed passage tombs of the Knowth and Newgrange complexes in the Brú na Bóinne and of the Mound of the Hostages, Tara. 
Additional work on the intriguing assemblage from Baltinglass would no doubt be worthwhile, including additional ${ }^{14} \mathrm{C}$ determinations (on calcined bone from all the deposits and charcoal once examined and identified to species), a reassessment of the potsherd from Chamber III and an attempt to source the stone used for the axehead. A new survey of the site, to address some of the questions about its structural history, would also be useful, as would a search for comparanda for the curious beehive structure, Chamber IV. In the meantime, however, the new information that has already been gathered has greatly improved our understanding of this complex, multi-phase monument, and its place in Irish prehistory.

\section{Acknowledgements}

We would like to thank the National Museum of Ireland for permitting sampling of the Baltinglass material, and Andy Halpin for his help during visits to the collections, and to Eleanor Standley and Andy Halpin for their comments on the dating of the lead button. Radiocarbon dating was undetaken at the ${ }^{14} \mathrm{CHRONO}$ facility of the School of Geography, Archaeology and Palaeoecology, Queen's University Belfast. Many thanks to Eileen Murphy and Barra Ó Donnabháin for allowing us to cite the early dates from Altanagh prior to publication, and to Billy O'Brien for the site photos. This research was undertaken and funded as part of the Heritage Council INSTAR Programme's (2008-2010) project entitled 'Cultivating Societies: Investigating the evidence for agriculture in Neolithic Ireland' (Ref: 16682)

\section{References}

ApSimon, A.M. 1986. Chronological contexts for Irish megalithic tombs. Journal of Irish Archaeology 3: 5-15.

Ashmore, P.J. 2004. Absolute chronology. In: I.A.G. Shepherd and G.J. Barclay (eds.), Scotland in Ancient Europe: The Neolithic and Early Bronze Age of Scotland in their European Context: pp. 125-136. Edinburgh: Society of Antiquaries of Scotland.

Bayliss, A., Bronk Ramsey, C., van der Plicht, J. and Whittle, A. 2007. Bradshaw and Bayes: towards a timetable for the Neolithic. Cambridge Archaeological Journal 17: 1-28.

Bayliss, A. and O'Sullivan, M. 2013. Interpreting chronologies for the Mound of the Hostages, Tara and its contemporary contexts in Neolithic and Bronge Age Ireland. In: M. O'Sullivan, C. Scarre and M. Doyle (eds.), Tara-From the Past to the Future. Towards a New Research Agenda: pp. 26-104. Dublin: Wordwell.

Bergh, S. 1995. Landscape of the Monuments. Stockholm: Arkeologiska Undersökningar 
Skrifter 6.

Bergh, S. 2002. Knocknarea: The ultimate monument. Megaliths and mountains in Neolithic Cúil Irra, north-west Ireland In: C. Scarre (ed.), Monuments and landscape in Atlantic Europe: pp. 139-151. London: Routledge.

Bergh, S. and Hensey, R. 2013. Unpicking the chronology of Carrowmore. Oxford Journal of Archaeology 32(4): 343-366.

Bradshaw, R. and McGee, E. 1988. The extent and time-course of mountain blanket peat erosion in Ireland. New Phytologist 108: 219-224.

Brindley, A.L., Lanting, J.N. and Mook, W.G. 1983. Radiocarbon dates from the Neolithic burials at Ballintruer More, Co. Wicklow, and Ardcrony, Co. Tipperary. Journal of Irish Archaeology 1: 1-9.

Bronk Ramsey, C. 2009. Bayesian analysis of radiocarbon dates. Radiocarbon 51(1): 337-360.

Buck, C.E., Cavanagh, W.G. and Litton, C.D. 1996. Bayesian Approach to Interpreting Archaeological Data. Chichester: John Wiley \& Son.

Bulfin, M., Radford, T. and Comey, A. 1979. Upland soils of Wicklow have good potential. Farm and Food Research 10(2): 36-38.

Burenhult, G. 1984. The Archaeology of Carrowmore. Stockholm: Theses and Papers in North-European Archaeology 14.

Burenhult, G. 2001. The Megalithic Cemetery of Carrowmore, Co. Sligo. Tjörnarp, Sweden: Göran Burenhult.

Collins, A.E.P. 1954. The excavation of a double horned cairn at Audleystown, Co. Down. Ulster Journal of Archaeology 17: 7-56.

Collins, A.E.P. 1981. The flint javelin heads of Ireland. In: D. Ó'Corráin (ed.), Irish Antiquity: Essays and Studies Presented to Professor M.J. O'Kelly: pp. 111-133. Dublin: Four Courts Press.

Cooney, G. 1981. A saddle quern from Baltinglass Hill, Co. Wicklow. Journal of the Royal Society of Antiquaries of Ireland 111: 102-106.

Cooney, G. 2000. Landscapes of Neolithic Ireland. London: Routledge.

Cooney, G. 2014. The role of cremation in mortuary practice in the Irish Neolithic. In: I. Kuijt, C.J. Quinn and G. Cooney (eds.), Transformation by Fire: The Archaeology of Cremation in Cultural Context: pp. 189-206. Tucson: University of Arizona Press.

Cooney, G., Bayliss, A., Healy, F., Whittle, A., Danaher, E., Cagney, L., Mallory, J.P., Smyth, J., Kador, T. and O'Sullivan, M. 2011. Ireland. In: A. Whittle, F. Healy and A. Bayliss (eds.), Gathering Time: Dating the Early Neolithic Enclosures of Southern Britain and Ireland: pp. 562-669. Oxford: Oxbow. 
Ditchfield, P. 2014. Stable isotope analysis. In: A. Lynch (ed.), Poulnabrone, Co. Clare. Excavation of an Early Neolithic Portal Tomb: pp. 86-92. Dublin: Department of Arts, Heritage and the Gaeltacht, Archaeological Monograph Series.

Eogan, G. 1974. Report on the excavations of some passage graves, unprotected inhumation burials and a settlement site at Knowth. Proceedings of the Royal Irish Academy 74C: 11-112.

Eogan, G. 1986. Knowth and the Passage-Tombs of Ireland. London: Thames and Hudson.

Eogan, G. and Roche, H. 1997. Pre-tomb Neolithic house discovered at Knowth, Co. Meath. Archaeology Ireland 11(2): 31.

Fowler, C. and Cummings, V. 2003. Places of transformation: building monuments from water and stone in the Neolithic of the Irish Sea. Journal of the Royal Anthropological Institute 9: 1-20.

Hartnett, P.J. 1971. The excavation of two tumuli at Fourknocks (sites II and III), Co. Meath. Proceedings of the Royal Irish Academy 71C: 35-89.

Hedges, R.E.M., Clement, J.G., Thomas, C.D.L. and O'Connell, T.C. 2007. Collagen turnover in the adult femoral mid-shaft: modeled from anthropogenic radiocarbon tracer measurements. American Journal of Physical Anthropology 133(2): 808-816.

Hemp, W.J. 1930. The chambered cairn of Bryn Celli Ddu. Archaeologia 30: 179-214.

Hensey, R. 2015. First Light: The Origins of Newgrange. Oxford: Oxbow Books.

Hensey, R., Meehan, P., Dowd, M. and Moore, S. 2014. A century of archaeology-historical excavation and modern research at the Carrowkeel passage tombs, County Sligo. Proceedings of the Royal Irish Academy C 114C: 57-87.

Herity, M. 1974. Irish Passage Graves. Dublin: Irish University Press.

Herity, M. and Eogan, G. 1977. Ireland in Prehistory. London: Routledge and Kegan Paul.

Hüls, C.M., Erlenkeuser, H., Nadeau, M.-J., Grootes, P.M. and Andersen, N. 2010. Experimental study on the origin of cremated bone apatite carbon. Radiocarbon 52(2-3): 587599.

Johnston, P. 2007. Analysis of carbonised plant remains. In: E. Grogan, L. O'Donnell and P. Johnston (eds.), The Bronze Age Landscapes of the Pipeline to the West: An Integrated Archaeological and Environmental Assessment: pp. 70-79. Bray: Wordwell.

Kador, T., Geber, J., Hensey, R., Meehan, P. and Moore, S. 2015. New dates from Carrowkeel. PAST 79: 12-14.

Lanting, J.N., Aerts-Bijma, A.T. and Van Der Plicht, J. 2001. Dating of cremated bones. Radiocarbon 43(2): 249-454. 
Lanting, J.N. and Brindley, A.L. 1998. Dating cremated bone: the dawn of a new era. Journal of Irish Archaeology 8: 25-42.

Lynch, A. (ed.) 2014. Poulnabrone: An Early Neolithic Portal Tomb in Ireland. Dublin: Department of Arts, Heritage and the Gaeltacht, Archaeological Monograph Series no. 9.

Lynch, A. and Ó Donnabháin, B. 1994. Poulnabrone portal tomb. The Other Clare 18: 5-7.

Macalister, R.A.S. 1932. A burial cairn on Seefin Mountain, Co. Wicklow. Journal of the Royal Society of Antiquaries of Ireland 62: 153-157.

McClatchie, M., Bogaard, A., Colledge, S., Whitehouse, N.J., Schulting, R.J., Barratt, P. and McLaughlin, R. 2014. Neolithic farming in north-western Europe: archaeobotanical evidence from Ireland. Journal of Archaeological Science 51: 206-215.

McClatchie, M., Bogaard, A., Colledge, S., Whitehouse, N.J., Schulting, R.J., Barratt, P. and McLaughlin, R. 2016. Farming and foraging in Neolithic Ireland: a review of the evidence from plant macro-remains. Antiquity 90: 302-318.

McKinley, J.I. and Bond, J.M. 2001. Cremated bone. In: D.R. Brothwell and A.M. Pollard (eds.), Handbook of Archaeological Sciences: pp. 281-292. Chichester: John Wiley \& Sons.

McLaughlin, T.R., Whitehouse, N.J., Schulting, R.J., McClatchie, M. and Barratt, P. 2016 (early view). The changing face of Neolithic and Bronze Age Ireland: a Big Data approach to the settlement and burial records. Journal of World Prehistory. doi: 10.1007/s10963-0169093-0.

McSparron, C. 2008. 'Have you no homes to go to?'. Archaeology Ireland 22: 18-21.

Meighan, I.G., Simpson, D.D.A., Hartwell, B., Fallick, A. and Kennan, P. 2003. Sourcing the quartz at Newgrange, Brú na Bóinne, Ireland. In G. Burenhult (ed.), Stones and Bones. Formal disposal of the dead in Atlantic Europe during the Mesolithic-Neolithic interface 6000-3000 BC: pp. 247-251. Oxford: Archaeopress, BAR International Series 1201.

Mitchell, A. 1884. On white pebbles in connection with Pagan and Christian burials, a seeming survival of an ancient custom. Proceedings of the Society of Antiquaries of Scotland 18: 286-291.

Mitchell, F. 1992. Notes on some non-local cobbles at the entrances to the passage-graves at Newgrange and Knowth, County Meath. Journal of the Royal Society of Antiquaries of Ireland 122: 128-145.

Murphy, E. and Ó Donnabháin, B. forthcoming. The People of Prehistoric Ireland. Dublin: Four Courts Press.

Nelis, E.L. 2004. Neolithic flint-work from the north of Ireland: some thoughts on prominent tool types and their production. In: A. Gibson and A. Sheridan (eds.), From Sickles to Circles. Britain and Ireland at the Time of Stonehenge: pp. 155-175. Stroud: Tempus.

O'Kelly, C. 1973. Passage-grave art in the Boyne Valley. Proceedings of the Prehistoric 
Society 39: 354-382.

O'Kelly, M.J. 1958. A horned-cairn at Shanballyedmond, Co. Tipperary. Journal of the Cork Historical and Archaeological Society 63: 37-72.

O'Kelly, M.J. 1982. Newgrange: Archaeology, Art and Legend. London: Thames and Hudson.

O'Kelly, M.J. 1989. Early Ireland. Cambridge: Cambridge University Press.

O'Sullivan, M. 1993a. Recent investigations at Knockroe passage tomb. Journal of the Royal Society of Antiquaries of Ireland 123: 5-18.

O'Sullivan, M. 1993b. Megalithic Art in Ireland. Dublin: Country House.

O'Sullivan, M. 2005. Duma na nGiall-The Mound of the Hostages, Tara. Dublin: Wordwell and University College Dublin.

O'Sullivan, M., Scarre, C. and Doyle, M. (eds.). 2013. Tara-From the Past to the Future. Towards a New Research Agenda. Dublin: Wordwell.

Raftery, J. 1973. A Neolithic burial mound at Ballintruer More, Co. Wicklow. Journal of the Royal Society of Antiquaries of Ireland 103: 214-219.

Robin, G. 2010. Spatial structures and symbolic systems in Irish and British passage tombs: the organization of architectural elements, parietal carved signs and funerary deposits. Cambridge Archaeological Journal 20(3): 373-418.

Schulting, R.J. 2011. The radiocarbon dates from Tullahedy. In: R.M. Cleary and H. Kelleher (eds.), Excavations at Tullahedy, Co. Tipperary, Neolithic Settlement in North Munster: pp. 145-161. Cork: The Collins Press.

Schulting, R.J. 2014a. Dating the construction of Newgrange. In: Ann Lynch, Newgrange revisited: new insights from excavations at the back of the mound 1984-5. Journal of Irish Archaeology 23: 46-50.

Schulting, R.J. 2014b. The dating of Poulnabrone, Co. Clare. In: A. Lynch (ed.), Poulnabrone: An Early Neolithic Portal Tomb in Ireland: pp. 93-113. Dublin: Department of Arts, Heritage and the Gaeltacht, Archaeological Monograph Series no. 9.

Schulting, R.J., Bronk Ramsey, C., Reimer, P.J., Eogan, G., Cleary, K., Cooney, G. and Sheridan, J.A. forthcoming. Dating the human remains from Knowth. In: G. Eogan and K. Cleary (eds.), Excavations at Knowth 6: The Archaeology of the Large Passage Tomb at Knowth, Co. Meath. Dublin: Royal Irish Academy.

Schulting, R.J., Murphy, E., Jones, C. and Warren, G. 2012. New dates from the north, and a proposed chronology for Irish court tombs. Proceedings of the Royal Irish Academy 112C: 160 .

Schulting, R.J., Sheridan, J.A., Crozier, R. and Murphy, E. 2010. Revisiting Quanterness: new AMS dates and stable isotope data from an Orcadian chamber tomb. Proceedings of the 
Society of Antiquaries of Scotland 140: 1-50.

Sheridan, J.A. 1986. Megaliths and megalomania: an account, and interpretation, of the development of passage tombs in Ireland. Journal of Irish Archaeology 3: 17-30.

Sheridan, J.A. 1995. Irish Neolithic pottery: the story in 1995. In: I.A. Kinnes and G. Varndell (eds.), 'Unbaked Urns of Rudely Shape': pp. 3-21. Oxford: Oxbow Monograph 55.

Sheridan, J.A. 2003. Ireland's earliest "passage" tombs: a French connection? In: G. Burenhult and S. Westergaard (eds.), Stone and Bones. Formal Disposal of the Dead in Atlantic Europe during the Mesolithic-Neolithic Interface 6000-3000 BC: pp. 9-26. Oxford: BAR International Series 1201.

Sheridan, J.A. 2010. The Neolithization of Britain and Ireland: the 'big picture'. In: B. Finlayson and G. Warren (eds.), Landscapes in Transition: pp. 89-105. Oxford: Oxbow.

Snoeck, C., Brock, F. and Schulting, R.J. 2014. Carbon exchanges between bone apatite and fuels during cremation: impact on radiocarbon dates. Radiocarbon 56(2): 591-602.

Stout, G. 1989. The Archaeology of County Wicklow. Archaeology Ireland 3(4): 126-131.

Stout, G. and Stout, M. 2008. Newgrange. Cork: Cork University Press.

Thompson, T. 2005. Clocha Geala/Clocha Uaisle: White quartz in Irish tradition. Béaloideas 73: 111-133.

Walshe, P.T. 1941. The excavation of a burial cairn on Baltinglass Hill, Co.Wicklow. Proceedings of the Royal Irish Academy 46: 221-236.

Whitehouse, N.J., Schulting, R.J., McClatchie, M., Barratt, P., McLaughlin, R., Bogaard, A., Colledge, S., Marchant, R., Gaffrey, J. and Bunting, M.J. 2014. Neolithic agriculture on the European western frontier: the boom and bust of early farming in Ireland. Journal of Archaeological Science 51: 181-205.

Woodman, P.C., Andersen, E. and Finlay, N. 1999. Excavations at Ferriter's Cove, 1983-95: Last Foragers, First Farmers in the Dingle Peninsula. Bray: Wordwell.

Zazzo, A., Saliège, J.-F., Lebon, M., Lepetz, S. and Moreau, C. 2012. Radiocarbon dating of calcined bones: insights from combustion experiments under natural conditions. Radiocarbon 54(3/4): 855-866.

Zazzo, A., Saliège, J.-F., Person, A. and Boucher, H. 2009. Radiocarbon dating of cremated bones : where does the carbon come from? Radiocarbon 51(2): 601-611. 


\section{Tables and Figures}

Table 1. AMS ${ }^{14} \mathrm{C}$ results on human bone and charred plant remains from Baltinglass. Sample E11:58-1 is on unburnt bone; all other human samples are fully calcined.

Figure 1. Map showing location of the Baltinglass passage tomb and other key sites mentioned in the text.

Figure 2. Baltinglass its landscape setting, with Chamber I to the left and Chamber III in immediate middle foreground. View to west. Photo: Professor William O’Brien.

Figure 3. Baltinglass, Chamber I. Part of Chamber II is visible to the upper right. View to s south. Photo: Professor William O’Brien.

Figure 4. Plan and section of the Baltinglass passage tomb (after Walshe 1941, plate XVIII, with overlain rock art rubbings from Figs. 8 and 9, not to scale), with approximate locations of main finds: 1) polished stone axe; 2) flint javelin head; 3) flint scrapers; 4) smooth, oval white pebble; 5) calcined bone pin and needle; 6) Carrowkeel pot sherds; 7) coarse pot sherd.

Figure 5. Unpublished plans of the Baltinglass passage tomb: a) sketch plan by Padraic T Breathnach specifying the locations of the cremated remains, dated 5/9/1934 (National Museum of Ireland archive); b) plan dated 1935, annotations as marked on original; note the different location of the southernmost motif on this and the published plan (' $G$ ' on Figure 4) (both figures redrawn by RJS).

Figure 6. Ground and polished greenstone axehead from black layer underlying the cairn (NMI E11:1).

Figure 7. Unburnt flint javelin head from black layer underlying the cairn (NMI E11:1).

Figure 8. Sherd of Carrowkeel ware from Chamber II (NMI E11:32).

Figure 9. Burnt bone pin fragments from Chamber III (NMI E11:37, 38).

Figure 10. Lead button, unknown find location (NMI E11:183).

Figure 11. Calibrated radiocarbon dates from Baltinglass (OxCal 4.2, using IntCal13). 


\section{NOTES}

Doherty, C., 1991. Palaeoecological investigations of a peat profile adjoining a Bronze Age passage grave at Seefin, County Wicklow. Unpublished B.Sc. Thesis, UCD, Dublin.

- peat profile on saddle between Seefin and Seefingan records land clearance features $>$ elm decline and rise in hazel and grasses, associated with passage tomb-builders?

\section{Athgreany stone circle}

Shee, E. 1972. Three decorated stones from Loughcrew, Co. Meath. Journal of the Royal Society of Antiquaries of Ireland 102(2): 224-233.

229/ penannular circles are equally rare in Passage Grave art, occurring at Baltinglass G, Tornant Upper (both Co. Wicklow) 